\title{
Karakteristik Tanda Kardinal Penyakit Skabies pada Santri di Pesantren
}

Yara Yuani Putri, ${ }^{1}$ Ratna Dewi Indi Astuti, ${ }^{2}$ Tryando Bhatara ${ }^{3}$

${ }^{1}$ Program Studi Pendidikan Dokter, ${ }^{2}$ Bagian Parasitlogi, ${ }^{3}$ Bagian Histologi dan Biologi Medik

Fakultas Kedokteran Universitas Islam Bandung

\begin{abstract}
Abstrak
Skabies merupakan suatu penyakit infeksi kulit yang menular. Penyakit ini dapat ditegakkan dengan menemukan dua dari empat tanda kardinal, yaitu gatal pada tempat predileksi terutama di malam hari, mengenai sekelompok orang, terdapat lesi terowongan pada kulit dan ditemukan tungau pada kerokan kulit. Penelitian ini bertujuan mengetahui karakteristik tanda kardinal penyakit skabies. Penelitian dilakukan di salah satu pesantren di Bandung dari bulan Maret sampai Oktober 2019. Subjek penelitian ini adalah penderita skabies sebanyak 43 orang. Penelitian ini bersifat deskriptif dan data dianalisis dengan analisis univariat. Pemeriksaan terowongan dilakukan dengan burrow ink test dan kerokan lesi dilakukan dengan teknik adhesive tape. Hasil penelitian menggambarkan bahwa papul merupakan morfologi lesi yang paling banyak ditemukan (86\%), lokasi lesi terbanyak ditemukan di sela-sela jari (65\%), hasil pemeriksaan positif pada burrow ink test sebanyak 14\% dan keseluruhan adhesive tape test menunjukkan hasil negatif. Terowongan dan tungau sulit ditemukan pada penderita skabies disebabkan oleh kerusakan kulit karena garukan dan jumlah tungau yang sedikit.
\end{abstract}

Kata kunci: Lesi, skabies, terowongan, tungau

\section{Characteristics of Cardinal Signs of Scabies in Santri at Islamic Boarding Schools}

\begin{abstract}
Scabies is a contagious skin infection. This disease can be diagnosed by finding two of the four kardinal signs, namely itching at the site of predilection, especially at night, concerning a group of people, the presence of tunnel lesions in the skin and the discovery of mites in skin scrapings. This study aims to determine the characteristics of kardinal signs in scabies. The study was conducted at one pesantren in Bandung from March to October 2019. Subjects in this study were 43 person with scabies. Tunnel checks are performed with a burrow ink test and lesion scrapings are carried out using an adhesive tape technique. The data of this descriptive research are analyzed by univariate analysis. The results showed that papules were the most common lesion morphology (86\%), most lesion locations were found between fingers (65\%), positive examination results on the burrow ink test were $14 \%$ and all adhesive tape test showed results negative. Tunnels and mites are difficult to find in people with scabies due to skin damage due to scratching and a small amount of mites.
\end{abstract}

Keywords: Lesion, mites, scabies, tunnel 


\section{Pendahuluan}

Penyakit skabies adalah penyakit infeksi kulit yang menimbulkan rasa gatal terutama pada malam hari sehingga dapat berdampak buruk bagi penderita seperti tidak nyaman, mengganggu tidur, dan mengganggu interaksi sosial. Penyakit skabies sangat mudah ditularkan melalui kontak antarkulit dan terjadi secara tidak langsung melalui pakaian ataupun dari tempat tidur. ${ }^{1}$

Prevalensi skabies di Indonesia menduduki urutan ketiga dari 12 penyakit kulit tersering. Prevalensi skabies berkisar $6-27 \%$ dari populasi umum serta puncaknya pada usia sekolah dan remaja dan biasa ditemukan pada lingkungan yang padat. Indonesia merupakan salah satu negara dengan tingkat kepadatan penduduk keempat di dunia. ${ }^{2}$

Skabies disebabkan oleh Sarcoptes scabiei merupakan varian hominis, filum Arthropoda, orde Akarina merupakan parasit obligat pada manusia yang berukuran 300-400 mikron. Tungau akan menggali terowongan pada stratum corneum dan melangsungkan siklus hidupannya dalam terowongan. Keadaan iklim tropis mendukung pertumbuhan parasit ini di Indonesia. ${ }^{3}$

Diagnosis skabies dapat ditegakkan dengan menemukan dua dari empat gejala kardinal, yaitu gatal-gatal hebat yang memburuk pada malam hari, infeksinya menyerang manusia secara kelompok, lesi berupa terowongan berbentuk garis lurus atau berkelok dengan rerata panjang $1 \mathrm{~cm}$ dan yang ujung terowongan itu ditemukan papul atau vesikel, serta ditemukan tungau. Penemuan tungau merupakan gold standard untuk mendiagnostik skabies. ${ }^{3,4}$

Lesi yang terdapat pada penyakit skabies pada umumnya berupa vesikel, papul, dan makula. ${ }^{4}$ Lesi patognomonis skabies adalah lesi terowongan yang berkelok-kelok dan pada ujungnya ditemukan papul. Namun, apabila sudah disertai dengan infeksi sekunder akan terdapat lesi tambahan seperti ekskoriasi, nodul, dan pustul. ${ }^{3,4}$

Tempat predileksi skabies tersebut biasanya di kulit dengan stratum korneum yang tipis, yaitu sela jari, pergelangan tangan, siku, lipat ketiak, areola, alat genital, bokong, dan kaki. Lokasi lesi skabies merupakan circle of hebra dan dapat menjadi awal penyebaran ke tempat lain dengan kontak langsung maupun kontak tidak langsung. ${ }^{5}$

Penelitian ini bertujuan mengetahui karakteristik dan tanda kardinal penyakit skabies berdasar atas jenis lesi, lokasi lesi, burrow ink test, dan adhesive tape test.

\section{Metode}

Penelitian ini merupakan penelitian bersifat deskriptif. Subjek pada penelitian ini adalah penderita skabies di salah satu Pondok Pesantren di Kabupaten Bandung. Waktu penelitian dimulai dari bulan Maret sampai Oktober 2019. Teknik pengambilan sampel penelitian ini adalah random sampling. Sampel minimal dibutuhkan 43 orang responden. Pemeriksaan penderita skabies dilaksanakan oleh tim dokter. Deteksi terowongan dilakukan dengan burrowink test. Kerokan kulit untuk menemukan tungau menggunakan teknik adhesive tape test. Aspek etika pada penelitian adalah sukarela, berhak menerima atau menolak, kebaikan, keadilan, dan tidak merugikan. Penelitian ini telah disetujui oleh Komite Etik Penelitian Kesehatan, Fakultas Kedokteran Universitas Islam bandung, dengan Nomor: 147/Komite Etik.FK/IV/2019.

\section{Hasil}

Morfologi lesi skabies dapat berupa papul, vesikel, makula eritema, pustul, nodul, dan ekskoriosis. Data sebaran penyakit skabies berdasar atas morfologi lesi pada santri dapat dilihat pada Tabel 1.

Tabel 1 Morfologi Lesi Skabies

\begin{tabular}{lcc}
\hline \multirow{2}{*}{ Morfologi Lesi } & Jumlah & Persentase \\
\cline { 2 - 3 } & $\mathbf{n = 4 3}$ & \% \\
\hline Papul & 37 & 86 \\
Vesikel & $\mathbf{2 1}$ & $\mathbf{2 8}$ \\
Makula eritema & $\mathbf{2 6}$ & 60 \\
Pustul & 7 & 16 \\
Nodul & 4 & 9 \\
Ekskoriasi & $\mathbf{1 4}$ & $\mathbf{1 4}$ \\
\hline
\end{tabular}

Tabel 1 menunjukkan bahwa dari 43 sampel penderita skabies, sebagian besar morfologi lesinya adalah papul. Mayoritas kedua paling banyak adalah makula eritema, kemudian yang sering muncul lagi adalah vesikel.

Lokasi lesi skabies biasanya menyerang circle of hebra, yaitu di sela sela jari, pergelangan tangan, gluteal, siku, ketiak, periumbilikal, genital, dan paha. Data sebaran penyakit skabies berdasar atas lokasi lesi dapat dilihat pada Tabel 2.

Tabel 2 Lokasi Lesi Skabies

\begin{tabular}{lcc}
\hline \multirow{2}{*}{ Lokasi Lesi } & Jumlah & Persentase \\
\cline { 2 - 3 } & $\mathbf{n = 4 3}$ & \% \\
\hline Sela-sela jari & $\mathbf{2 8}$ & 65 \\
Siku & $\mathbf{1 1}$ & 26 \\
Gluteal & 11 & 26 \\
Ant. pergelangan tangan & 26 & 90 \\
Periumbilikal & 2 & 5 \\
Genital dan paha & $\mathbf{1}$ & 2 \\
Ketiak & 3 & 7 \\
\hline
\end{tabular}

Tabel 2 menunjukkan dari 43 sampel penderita skabies, sebagian besar lokasi lesinya berada di selasela jari.

Burrow ink test itu merupakan pemeriksaan penunjang pada penderita skabies untuk menemukan terowongan pada lapisan kulit. Pemeriksaan ini cukup sederhana, cepat, tidak invasif, dan ekonomis. Hasil pemeriksaan lesi terowongan dengan burrow ink test hanya ditemukan 6 dari 43 yang positif (14\%). Adhesive tape test merupakan pemeriksaan gold 
standard untuk menegakkan penyakit skabies dengan ditemukan tungau atau skibala di bawah mikroskop. Pemeriksaan ini cepat, sederhana, dan tidak bersifat invasif. Hasil pemeriksaan adhesive tape test positif tidak ada, semuanya negatif.

\section{Pembahasan}

Gambaran jenis lesi yang ditemukan pada penelitian ini bervariasi berupa papul, vesikel, makula eritema, pustul, nodul, dan ekskoriasi. Persentase morfologi lesi skabies tertinggi adalah papul. Hal ini sesuai dengan penelitian Nasution dkk. ${ }^{6}$ tahun 2012 bahwa morfologi lesi tertinggi adalah papul (87,7\%). Walter dkk.7 tahun 2011 juga mendapatkan jenis lesi terbanyak yang ditemukan berupa papul (70\%). Hasil penelitian Riyanto ${ }^{8}$ tahun 2016 juga menemukan lesi papul pada seluruh penderita penyakit skabies (100\%). Papul merupakan lesi yang sering dijumpai pada penderita skabies karena Sarcoptes scabiei memproduksi banyak produk saliva saat membentuk terowongan dan merupakan sumber molekul yang dapat memodulasi sekresi anti-inflammatory cytokine pada kulit manusia. Hal ini dapat menyebabkan sensitisisasi limfosit $\mathrm{T}$ yang akan merangsang reaksi hipersensitivitas tipe 4. Reaksi ini akan mengakibatkan proliferasi fibroblas dan kolagen amengakibatkan penebalan lapisan kulit dan terbentuk papul. ${ }^{9}$ Selain papul, lesi lain yang ditemukan adalah vesikel yang merupakan perkembangan papul. Garukan pada lesi dapat menyebabkan lesi makula eritema, ekskoriasi, serta infeksi sekunder yang ditandai dengan pustul. Pustul yang muncul pada infeksi sekunder merupakan progresivitas papul menjadi vesikel, kemudian terifeksi bakteri sehingga menghasilkan pus. Bakteri yang paling sering menginfeksi adalah Staphylococcus aureus. ${ }^{10}$

Sebaran lokasi lesi timbul pada penderita skabies terbanyak pada sela-sela jari dan pergelangan tangan. Hal ini sesuai dengan penelitian Tediantini ${ }^{11}$ tahun 2016 bahwa lokasi yang paling sering berada di daerah sela jari sebanyak $43 \%$. Pada penilitian Sivalingam ${ }^{12}$ tahun 2017 lokasi lesi paling banyak pada pergelangan tangan (98\%). Keadaan ini terjadi karena pergelangan tangan dan sela-sela jari merupakan area dengan stratum korneum yang tipis sehingga tungau Sarcoptes scabiei lebih mudah membuat terowongan. ${ }^{13}$

Pada pemeriksaan Burrow ink test pasien skabies pada penelitian ini menunjukkan hasil yang positif hanya sebanyak $14 \%$. Hal ini sesuai dengan penelitian yang dilakukan oleh Cassell dkk. ${ }^{15}$ tahun 2018 bahwa pemeriksaan Burrow ink test positif hanya sebanyak 7\%. Terowongan pada kulit merupakan patognomonis penyakit skabies, namun ciri khas patognomonis ini sulit teridentifikasi. ${ }^{15}$ Kesulitan identifikasi disebabkan antara lain oleh krusta dan pustul yang menyebabkan tinta tidak dapat masuk ke dalam terowongan serta garukan pada lesi yang merusak terowongan..$^{15,16}$

Pemeriksaan penunjang lainnya adalah adhesive tape test merupakan gold standard untuk menemukan tungau atau skibala. Namun, pada penelitian ini hasil semuanya negatif. Hal ini sesuai dengan penelitian Stolz dkk. ${ }^{17}$ tahun 2011 yang menunjukkan hasil yang positif sebanyak 9,5\%. Hal ini terkait dengan beberapa kemungkinan, di antaranya garukan yang dapat menghilangkan tungau pada lapisan kulit. Selain itu, telur yang dihasilkan oleh tungau betina kurang dari $10 \%$ yang menjadi tungau dewasa sehingga pada seorang penderita biasanya hanya terdapat 11 tungau betina yang menjadi dewasa. Adhesive tape test memiliki sensitivitas yang rendah dibanding dengan dermoscopy yang memiliki manfaat untuk diagnosis skabies yang lebih baik. Pada penelitian ini tidak dilakukan terlebih dahulu pemeriksaan dermoscopy menyebabkan hasil pemeriksaan tersebut tidak maksimal. ${ }^{10}$

\section{Simpulan}

Morfologi lesi yang paling sering ditemukan adalah papul, lokasi lesi yang paling banyak di sela-sela jari dan pergelangan tangan, hasil positif pada pemeriksaan terowongan dengan burrow ink test hanya sepertujuh dan tidak ada pemeriksaan tungau dan skibala yang positif dengan adhesive tape test.

\section{Daftar Pustaka}

1. Prayogi S, Kurniawan B. Pengaruh personal hygiene dalam pencegahan penyakit skabies. Med J Lampung University. 2016;5(5):140-3.

2. Santiya S. Gambaran kejadian skabies, gejala klinisi, faktor risiko dan penatalaksanaannya di kalangan anak-anak di Desa Nelayan Kecamatan Medan Marelan. Medan: Universitas Sumatera Utara; 2017.

3. Dewi MK, Wathoni N. Artikel review: diagnosis dan regimen pengobatan skabies. Farmaka. 2017;15(1):122-33.

4. Clyti E, Deligny C, Versapuech J, Couppie P, Gessain A, Pradinaud R. Acral crusted scabies in two HTLV1-infected patients. Ann Dermatol Venereol. 2016;137(3):232-3.

5. Banerji A. Scabies. Paediatr Child Health. 2015;20(7):395-8.

6. Nasution SF, Tanjung C, Lakswinar S. Karakteristik pasien skabies di SMF ilmu kesehatan kulit dan kelamin RSUP H. Adam Malik Medan periode Januari 2010-Desember 2012. Maj Kedokt Nusantara. 2012;45(3):158-61.

7. Walter B, Heukelbach J, Fengler G, Worth $C$, Hengge U, Feldmeier $H$. Comparison of dermoscopy, skin scraping, and the adhesive tape test for diagnosis of scabies in a resource-poor setting. Arch Dermatol. 2011;147(4):468-73.

8. Riyanto P. Uji diagnostik pemeriksaan dermatoskopik dibandingkan baku emas pemeriksaan mikroskopik dalam menegakkan diagnosis scabies. Semarang: Fakultas Kedokteran Universitas Diponegoro; 2006.

9. Burns DA. Diseases caused by arthropods and other noxious animals. Dalam: Burns T, Breathnatch S, Cox N, Griffiths C, penyunting. Rook's text book of dermatology. Edisi ke-8. London: Blackwell Publishing; 2010.

10. Sungkar S. Skabies. Depok: Badan Penerbit 
Fakultas Kedokteran Universitas Indonesia; 2016.

11. Tediantini PN. Profil penyakit skabies pada anakanak SMP di Yayasan Al Islam Hidayatullah kota Denpasar, Bali tahun 2014. E-Jurnal Medika Udayana. 2016;5(12):1-4.

12. Sivalingam S. Gambaran kejadian skabies, gejala klinisi, faktor risiko dan penatalaksanaannya di kalangan anak-anak di Desa Nelayan Kecamatan Medan Marelan. Medan: Universitas Sumatera Utara; 2017.

13. Leone PA. Pubic lice and scabies. Dalam: Wolff K, Goldsmith L, Katz S, Gilchrest B, Paller A, Leffell $\mathrm{O}$, penyunting. Fitzpatrick's dermatology in general medicine. Edisi ke-7. New York: McGrawHill; 2008. hlm. 839-50.

14. Stone SP, Goldfarb JN, Bacelieri RE. Scabies, other mites, and pediculosis, Dalam: Wolff K, Goldsmith L Katz S, Gilchrest B, Paller A, Leffell
O, penyunting. Fitzpatrick's dermatology in general medicine. Edisi ke-7. New York: McGrawHill; 2008. hlm. 2029-37.

15. Cassell JA, Middleton J, Nalabanda A, Lanza S, Head MG, Bostock J, dkk. Scabies out-breaks in ten care homes for elderly people: aprospective study of clinical features, epidemiology, and treatment outcomes [Internet]. Lancet Infect Dis. 2018 Aug;18(8):894-902.

16. Mellanby K. Scabies in 1976 [Internet]. R Soc Health J. 1977 Feb;97(1):32-6.

17. Stolz W, Braun-Falco O, Semmelmayer U, Kopf AW. History of skin surface microscopy and dermoscopy. Dalam: Marghoob AA, Braun RP, Kopf AW, penyunting. Atlas of dermoscopy encyclopedia of st visual medicine series. Edisi ke1. London: Taylor and Francis; 2005. hlm. 1-6. 